\title{
Sustainable development and national cultures: a quantitative and qualitative analysis of the research field
}

\author{
Katarzyna Piwowar-Sulej ${ }^{1}$ (D)
}

Received: 21 April 2021 / Accepted: 25 November 2021 / Published online: 7 December 2021

(c) The Author(s) 2021

\begin{abstract}
National culture (NC) plays a crucial role in transitioning societies toward sustainable development (SD) which is based on the triple bottom line (TBL) approach. The impact of NC should be broadly analyzed, taking into account the perspective of individuals, organizations, societies, etc. This constitutes the general field of "national culture sustainable development" (NCSD). To the author's knowledge, this is the first literature review conducted on the above-defined NCSD field and based on a mixed-methods analysis. It contributes to the development of knowledge by presenting the scientific structure of the general NCSD research field and the main detailed problems addressed in the papers assigned to this field, synthesizing the previous research findings, and emphasizing the need to examine SD holistically. This study revealed that the interest of academics in the NCSD field is growing. The scientific structure of this field is formed by 80 articles, including 63 empirical papers which were based mostly on the analysis of secondary data. The most popular topic in previous studies was the relationship between cultural dimensions (authored by Hofstede) and practices related to reporting on sustainability. Cultural characteristics were combined with the data from different sources and covered different numbers of countries. Subsequent research projects were methodologically separate from the previous ones which implied inconsistent results. Papers discussing the linkage between national culture and all elements of the TBL concept together are rare. The above highlights, i.e., the need for more research based on a holistic approach to SD, methodological rigor and continuity.
\end{abstract}

Keywords Sustainability $\cdot$ Triple bottom line $\cdot$ Literature review $\cdot$ Hofstede $\cdot$ Culture

\section{Introduction}

The most common definition of sustainable development (SD) describes the concept as "meeting the needs of the present generation without compromising the ability of future generations to meet their own needs"(World Commission on Environment and Development, 1987, p. 49). In this definition, all three aspects of the so-called "triple bottom line"

Katarzyna Piwowar-Sulej

Katarzyna.piwowar-sulej@ue.wroc.pl

1 Wroclaw University of Economics and Business, Komandorska 118/120, 53-345 Wrocław, Poland 
(TBL) (authored by Elkington 1997) i.e., profit, natural resources, and people align, constituting the pillars of sustainability.

As Zheng et al. (2021) stated, "the role of culture in sustainable development varies with different interpretations of culture" (Zheng et al., 2021, p. 308). A function-oriented definition associates culture with cultural industries which produce cultural services and goods. In turn, in the constituent interpretation, culture creates assumptions about how the world functions, and those assumptions drive a huge piece of humans' behavior, it is a "way of life" (Williams, 1988), "the collective programming of the mind that distinguishes one group of people from another" (Hofstede, 1991, p. 40).

In international projects devoted to the integration of culture in SD, the term "culture" is often used in both senses (Zheng et al., 2021); however, this study focuses on the constituent interpretation of culture. Culture (including national culture) as stems from the abovepresented definitions plays a crucial role in the transition of societies toward a desired condition. As Parker (1997) stated, national culture is a "critical factor affecting economic development, demographic behavior, and general business policies" (Parker, 1997, p. 1). In turn, Zhu et al. (2018) emphasized the role of cultural values as determinants of countries' innovation performance (and, hence, economic development).

Globalization is one of the drivers for the growing interest in cultural issues (Worthington et al., 2018). Taking into account the differences between countries is crucial for successfully operating on global markets (Pagell et al., 2005). For decades, the impact of national culture on organizational culture has been the subject of ongoing debates in the academic literature on organizational theory (Ellis \& Thompson, 1997; Minkov \& Hofstede, 2012; Owusu Ansah \& Louw, 2019; Willmott, 2000; Yoder-Wise, 2018). Researchers have examined the role of national culture in managerial decision-making, leadership styles, and communication (Ayub Khan \& Smith Law, 2018), as well as such specific domains as operations management (e.g., Clay Whybark, 1997; Pagell et al., 2005)), quality management (e.g., Ettlie, 2009; Islam, 2013)), knowledge management (Anantatmula, 2010), and environmental management (Klassen \& Angell, 1998) since all cultures have their own way of perceiving the world a "worldview" and this informs the way communities of people behave toward the environment (Roskruge, 2011).

As stated above, different researchers have emphasized the role of culture in achieving economic goals as well as environmental performance. Wilson (2015) points out that economic sustainability depends on an appropriate degree of sustainable development in terms of environmental and social outcomes. Beyond the economic and environmental bottom lines, SD is based on the third social bottom line. The three elements of the TBL may be analyzed in the context of individuals, organizations, countries, etc. (de Lange et al., 2012). Moreover, they are interconnected (Correia, 2019), which justifies taking into account the publications in which SD is identified with selected pillars of sustainability, particularly appreciating papers that explore the linkage between national culture and all elements of the TBL treated equally. Finally, TBL issues include the formulation of goals, the selection of means, and the achievement of results (Shi et al., 2019).

At this point it is worth emphasizing that culture impact the behavior of individuals, organizations, societies, etc. Data related to the TBL may also be analyzed from the perspective of individuals (e.g., state of health, economic well-being, or green behavior), companies (e.g., employee well-being, financial profits, or reduction of waste), or countries (e.g., quality of education, level of economic development, or total greenhouse gas emission). Therefore, studies on the linkage between national culture and outcomes related to environmental, social, and financial issues should not be limited only to one level of analysis. 
Since the development of any research field should be based on appropriate foundations, one of the researcher's roles is to provide an analysis, comparison, and synthesis of previous findings (Paul \& Criado, 2020). The influences of culture on sustainability is fragmented and scattered (Zheng et al., 2021). Previous authors who have focused on the relationship between national culture and sustainability-related issues have provided some literature reviews. For example, Renwick et al. (2016) reviewed only articles published in a special issue and slightly indicated the relationship between national culture, organizational culture, and corporate environmental sustainability. In their meta-analysis, Morren and Grinstein (2016) examined how national culture (two dimensions distinguished in Hofstede's typology) impacts the environmental behavior of individuals. In turn, Adedeji et al. (2017), in their literature reviews, focused on the relationship between national culture (its dimensions from Hofstede's model) and the sustainability disclosure practices of companies, but they did not present the methodological aspects of reviewing the literature. Finally, Zheng et al. (2021) synthesized scholarly knowledge from 300 publications looking for a link between cultural values and society's achievement of sustainable development goals, but did not present the method of document selection, any bibliometric characteristics, or the method of content analysis used in their review. To the best of the author's knowledge, no comprehensive, methodologically-grounded bibliometric and qualitative literature reviews combining national culture with sustainable development and focusing on the TBL has been published so far. This research is intended to fill this gap. In particular, it answers the following research questions:

RQ1 What is the scientific structure of the general NCSD research field? This structure contains such data as research productivity in terms of the number of publications and the number of citations received, networks of researchers and keywords, the frequencies of theoretical versus empirical articles, and methods used in empirical research.

$R Q 2$ What are the main detailed problems addressed in the papers assigned to this research field?

$R Q 3$ Which elements of the TBL are discussed most in the papers? How many studies strictly address all the elements together?

$R Q 4$ What are the research findings on the relationships between national culture and a comprehensive approach to sustainable development (addressing all elements of the TBL together)?

$R Q 5$ What are the future directions for researchers in the field of NCSD?

The aim of this study, answering the above-presented questions, is consistent with the basic functions of literature reviews (Assunta Di Vaio, Palladino et al., 2020; Vaio et al., 2020; Piwowar-Sulej, 2021). Moreover, this article applies a mixed-methods approach, combining scientometric analysis with qualitative in-depth studies. The main advantage of scientometric methods is that they introduce quantitative rigor into the subjective evaluation of scholarly literatures (Assunta Di Vaio et al., 2021; Zhang et al., 2017). They generate practical information referring to the evaluation of the scientific activity (CapobiancoUriarte et al., 2019; Rey-Martí et al., 2016). In turn, in-depth analysis gives deeper insight into the findings of previous research.

This research presents several contributions to the field and to a diversified audience. As a result, this study allows the main trends of the scientific output in the analyzed area to be identified within 80 documents obtained from the Scopus database. It also allows the researchers to put forward insights into the topical interests (Camón Luis \& Celma, 2020). Importantly though, this study contributes to the development of knowledge not only by 
providing such analyses and their results, but also by presenting directions for further academic research. Finally, as mentioned above, taking into account the results presented by the Scopus database, this article is a pioneering one as far as literature reviews on NCSD are concerned.

The remaining part of this paper is organized as follows. The second section presents the literature background. It discusses the meaning of SD in terms of the TBL and the essence of national culture, and it briefly presents cultural typologies, which will be a subject of analysis in the empirical part of the paper. The research methodology used for the purposes of this study is described in the third section. The fourth part of the article shows the research results, which are divided into subsections according to the detailed methods used in the literature review. The research findings are then discussed and the answers to the research questions are provided. The next section presents theoretical and practical contributions, followed by the conclusions and directions for further research related to this study's limitations.

\section{Literature background}

\subsection{Sustainable development and triple bottom line approach}

Sustainable development gained wide recognition in the scientific and professional community after the Brundtland Commission (1987) published the report "Our Common Future," which emphasized that Earth's resources are being used at a rate that will leave little for future generations. In this environmental context, the concept of SD emerged and became a significant strategy to guide the world's transformation (Klarin, 2018).

The definition of SD presented in the Introduction has been broadly disseminated and adopted by organizations such as the United Nations (2020). However, a lack of understanding of SD still exists among state agencies, academia, and companies (Broman \& Robèrt, 2017). For example, the description of SD does not distinguish between goals, means, and results (Shi et al., 2019). Moreover, the concept of SD is still being developed, including micro- and macro-perspectives, and new elements (goals, types of activities, and results) are being introduced and analyzed within this concept (Piwowar-Sulej et al., 2021).

The triple bottom line approach is a basic approach in measuring impact and success within SD. Although this framework was built by an entrepreneur Elkington (1997) and was initially designed for business, the way of thinking about SD may be related to the goals, means, and results of individuals, companies, societies, etc. (de Lange et al., 2012).

For example, the global perspective of SD is expressed in the list of goals set by the United Nations (2016). This list highlights global challenges in terms of the environmental bottom line (e.g., clean water), global profit (e.g., decent economic growth), and the social bottom line (e.g., peace). In turn, ISO 26000 lists the principles of SD as guidelines for companies. However, behaviors and their outcomes in relation to the TBL may be also analyzed from the perspective of an individual, as justified in studies devoted to, for example, the problem of individual values or motivations toward sustainability-oriented behavior.

As stated in the Introduction, the three elements of the TBL are interconnected. This may be simply explained through the process of deduction. From the perspective of an individual, using a bicycle instead of a car may positively impact not only the natural environment, but also the individual's health (and well-being) and savings. The reciprocal relationships between the results obtained by countries in terms of the TBL has been 
empirically proven as well (Dörgő et al., 2018). However, the natural environment has been recognized as fundamental for the achievement of other pillars of sustainability (Scharlemann et al., 2020). Therefore, academic databases include works which use the term "sustainable development" but which focus on one or more elements of the TBL. All those studies help develop the general SD field. Nevertheless, it is worth striving for comprehensiveness in academic work (Milne, 2017) and highlighting as in this study works that deal with the problem holistically.

\subsection{The essence of national culture}

The main elements of the constituent interpretation of national culture are values and norms, beliefs, attitudes, and behaviors that are shared among members of a nation (Crane et al., 2008). Values are something we believe we deserve. Values and norms provide guidelines regarding unacceptable and acceptable behavior in a society (Cialdini et al., 1991; Rokeach, 1973) and are broadly based. Beliefs are defined as "probability dimensions of a concept (treated as relational statement)" (Fishbein, 1963, p. 233). Attitudes can be associated with "affective evaluations (favorable or unfavorable) with regard to particular objects or behaviors" (Kroesen et al., 2017, p. 190). Behaviors can be defined as manifestations of values and attitudes, though it has been empirically proven that some beliefs and attitudes can mediate the relationship between values and behavior (Alwitt \& Pitts, 1996). It is worth mentioning that culture is not the same as behavior, but an abstraction from a particular behavior (Chanchani \& Theivananthampillai, 2009). As Jones (2007) stated, shaping culture is a slow process which covers spreading and learning values (prevailing beliefs and attitudes), taking part in rituals (undertaking collective activities), modeling roles, and understanding symbols (language, myths, and legends). Symbols (e.g. language or religion) are also components of culture (Beyers, 2017).

As indicated in the Introduction, the impact of national culture is reflected on different levels from the individual to the wider community. At this point it is worth emphasizing that in the literature on the subject organizations are seen as having particular importance in transforming societies toward sustainability (Dubey et al., 2017; Hopwood et al., 2005). National cultural values can influence the way people set up and develop organizations (Owusu Ansah \& Louw, 2019). In turn, organizational culture has an impact on an organization's performance (Cameron et al., 2006). Therefore, they are regarded as a strategic element taking into account a resource-based theory of organization (Genç, 2013).

On the grounds of institutional theory, the impact of national culture on organizational culture can be explained in the following way: organizations conform to society's values and as a result gain acceptance and obtain the necessary resources (Chen \& Roberts, 2010). In turn, on the basis of stakeholder theory, the role of an organization is to respond to the expectations of its stakeholders and a society along with its culture can be treated as a stakeholder (Henriksson \& Weidman Grunewald, 2020).

As far as the differences between national and organizational culture are concerned, one can state that national cultural features "are rooted in values learned before age 10; children learn them from parents who also acquired them before age ten, so they are quite stable and take generations to be changed" (Hassan Elsan Mansaray \& Hassan Elsan Mansaray Jnr, 2020 , p. 184). In turn, the characteristics of organizational cultures are deep-rooted in the activities learned in the workplace and thus may change faster than national culture. 


\subsection{Typologies of national cultures}

Since culture is an important aspect of one's private and business life, cultural studies try to diagnose and measure it in order to provide information about the desired and current cultural characteristics and to pave the way for cultural changes and further research. Hofstede's cultural dimensions theory provides the most well-known classification used in studies on national culture (Chanchani \& Theivananthampillai, 2009; Smith \& Bond, 2019). However, there are also typologies such as those written by Trompenaars and Hampden-Turner or Triandis and Fiske.

Hofstede's typology of cultures is based primarily on four dimensions. The fifth dimension was introduced in 1988 (Hofstede \& Bond, 1988) and the last one came decades later (Hofstede et al., 2010). Individualism versus collectivism represents the first cultural dimension. Individualism emphasizes the rights of the individual person and their individual goals. In turn, collectivism focuses on personal relationships and group goals (achieving what is best for the whole group) (Hofstede, 1984). The second dimension reflects power distance (large versus small). Power distance is associated with the level of the acceptance of unequally distributed power and wealth in a society or a group (Alper, 2019). The third dimension covers uncertainty avoidance (strong versus weak). It reflects the extent to which members of a society try to minimize uncertainty, for example by setting clear rules (Snitker, 2010). The fourth dimension is masculinity versus femininity. Masculinity reflects a strong orientation toward traditional men's and women's roles, ambition, and economic success, whereas femininity stands for a modest, relationship-oriented society (Hofstede, 2016). The fifth dimension is term orientation (long versus short). Long-term orientation means strategic thinking and preparing for the future, whereas short-term-oriented societies focus on the past (tradition) and present (Guo et al., 2018). Finally, the sixth dimension is indulgence. Societies with high indulgence encourage their members to freely satisfy their basic needs (having control over their lives) and use less stringent social norms (Hofstede et al., 2010).

The classification by Trompenaars and Hampden-Turner (1997) distinguishes five cultural dimensions: universalism versus particularism, individualism versus communitarianism (collectivism), neutral versus emotional (affective), diffuse versus specific, achievement versus ascription, attitude to time (sequential versus synchronic), and internal versus external control (attitude to one's environment). To avoid redundancy, only the new dimensions (those which are absent in Hofstede's typology) are characterized below.

Universalism applies the same rules to everybody; particularism, on the contrary, takes into account specific circumstances in applying the rules. A neutral culture restrains emotions, while an emotional culture allows for their natural expression. A specific culture establishes an open public space shared by everybody and a private milieu accessible to one's close friends alone. In a diffuse culture, both public and private spaces are carefully guarded by the individuals, as access to one of them provides access to the other. It examines to what extent culture keeps private and public lives separate. In an achievement culture, status is assigned based on individual accomplishments. An ascription culture is focused on inherited titles or ranks. An inner-directed culture believes in controlling the surrounding world, whereas an outer-directed culture allows flexibility and compromise and avoids control over the environment (Trompenaars \& HampdenTurner, 1997).

Triandis (1994) determined four cultural symptoms that may be applied to all cultures: cultural tightness, cultural complexity, individualism, and collectivism. In "tight" 
cultures individuals are expected to behave in line with clearly defined norms. In turn, in loose cultures deviations from these norms are accepted. Cultural complexity is related to the number of different cultural elements (e.g., role definitions) (Triandis, 1996). Hofstede also distinguished individualist and collectivist cultures, but Triandis suggested that individualism and collectivism can be analyzed from a horizontal or vertical perspective. Horizontal individualists aim to be unique, whereas vertical individualists desire to be "number 1." Horizontal collectivist people simply work in teams, whereas vertical collectivists are able to sacrifice themselves for their teams (Triandis, 2001).

National cultures can also be categorized on the basis of the following four relational models created by Fiske (1992). The first model is communal sharing relationships, treated as the most basic form of relationship when a group disregards individual identities and emphasizes commonalities. The second model, authority ranking, based on linear ordering and hierarchy, divides people into those with higher rank, privileges and responsibilities superiors who make decisions and those lower in rank, subordinates who require protection. In equality matching relationships, there is no authority between people or responsibility toward one another, but a balanced exchange instead. Finally, market pricing relationships are based on value and worth (e.g., setting appropriate prices).

\section{Material and methods}

Literature studies should begin by choosing the database(s) and determining the selection criteria for publications, such as the search terms and dates of publication (Lewis et al., 2011). The initial process also involves extracting articles from databases and identifying relevant articles (Assunta Di Vaio et al., 2020; Vaio et al., 2020).

This research project was carried out from January to May 2021 and focused on articles indexed in the Scopus database. Figure 1 presents the queries which were used in the searching process as well as the way the final sample of documents was obtained.

The author used the Scopus database because it has a better coverage of journals in different research fields focusing on management and the social sciences (Mongeon \& PaulHus, 2016). The search areas were titles, abstracts, and keywords.

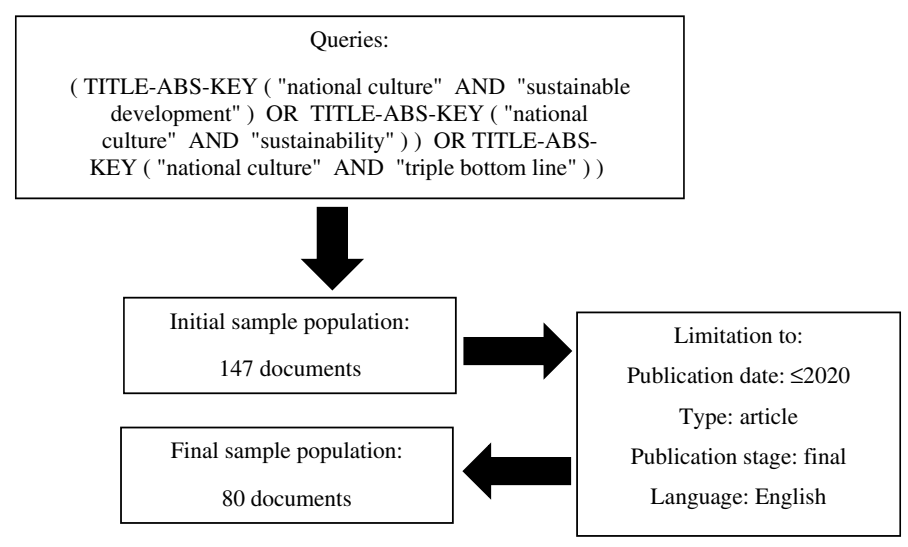

Fig. 1 The process from initial to final sample population while searching in Scopus data collected on January 3,2021 
A database including bibliometric data related to all documents from the sample was imported as RIS and CSV files. In the next step, the author checked whether all extracted articles were relevant. A content analysis was carried out by reading the abstracts, as presented by Di Vaio et al. (2020), Vaio et al. (2020)), Alvino et al. (2020), and Del Giudice et al. (2021). All articles addressed the field of NCSD. The graphical presentations accessible in Scopus and the original calculation made in Microsoft Excel were used when providing the bibliometric analysis. Bibliometric indexes such as the number of publications and the number of citations were used to analyze data, as described by Khan et al. (2020). The RIS file downloaded from Scopus was used as the input file for network analysis using the software VOSViewer (van Eck \& Waltman, 2014); the network analysis was based on Ferasso and Cherobim's (2017) guidelines.

The first test was devoted to the issue of co-authorship when authors were the unit of analysis. The exploratory analysis was performed with a minimum of two documents by an author; only four authors met this threshold. This procedure in general allows for the creation of a network of the most productive co-authors, but not in this case, as presented in Table 1.

The second network analysis was based on keywords. As Chen and Xiao (2016) stated, an analysis of keywords enables the specific details in the main topics of research within a domain and relationships to be studied at the micro-level. First, following the guidelines presented by van Eck and Waltman (2014), the minimum number of occurrences of keywords was set to five. With this parameter, 305 identified author keywords were scanned, and only six met the threshold. In order to identify possible research gaps for future studies and due to the fact that only six keywords met the threshold, a minimum of two occurrences of keywords was chosen. As a result, 31 keywords met the threshold. The final network of keywords was formed by 30 items (one item was not connected to the other items) and consists of seven clusters; the network is presented in Fig. 4. The larger cluster is made up of seven associated keywords, the next five consist of four keywords, and the seventh has three keywords.

The qualitative analysis of this study was focused on the type of article (theoretical vs. empirical), the scope of elements of the TBL (environmental, economic, and social) which were explored in the study, the detailed topic, and the cultural typology and methods of empirical research used by the researchers.

Finally, the author downloaded all the papers and manually scanned their content to find studies which simultaneously addressed issues related to the environmental, economic, and social bottom lines. This resulted in eight papers (see Appendix, Table 5). This paper comprises a synthesis of these studies (Cooper, 2010).

The next section of this article presents the quantitative bibliometric characteristics of the sample of 80 documents and provides data which come from the in-depth content analysis of the above-mentioned 10 articles. 


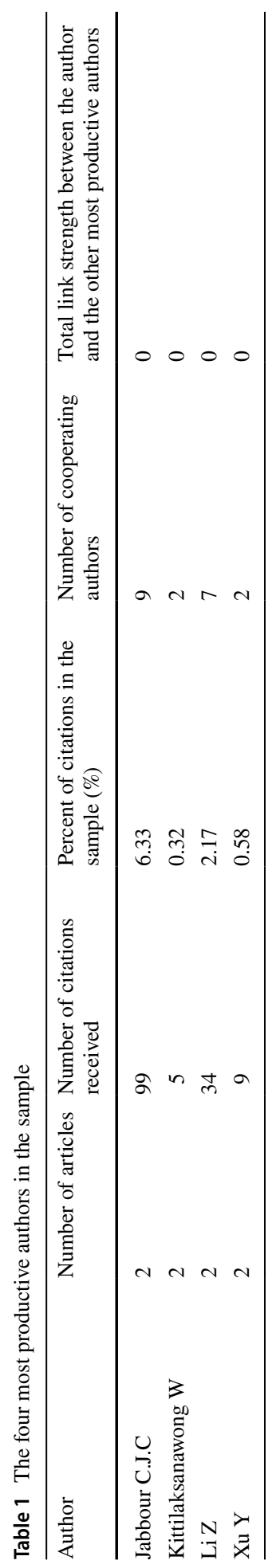




\section{Results}

\subsection{Bibliometric characteristics of the articles which link national culture and sustainable development}

The analyzed sample included articles dated between 1999 and 2020 (Fig. 2). In 1999 two articles were published, one written by Zhuge, R. and Tisdell C. and cited only once, and one written by Yan F., Liu D.-M.and Yang H.-P., with no citations.

Taking into account the whole period of study, one can observe the growing interest in this field of knowledge; however, this growth is not constant. There were years in which the number of publications was lower than in previous years (e.g., 2008 and 2013). There are also pairs of years when the number of publications was stable (e.g., 2009-2010 or 2011-2012).

As Fig. 3 shows, the majority of articles come from the USA. However, Australia and Asian and Western European countries are also included on the list of the most represented research locations.

As indicated in the methodological section of this paper, VOSViewer was used to identify co-authorship networks. The 80 articles were written by 206 authors in total and were authored by up to six individuals. As presented in Table 1, the most productive authors did not cooperate with each other.

The total number of citations received by all analyzed documents was 1,564. As indicated above (Table 1), the most productive author is not the most cited author; he received 99 citations, whereas the most cited paper, authored by Ho, L.-C.J. and Taylor, M.E. (Appendix, Table 5), received 193 citations.

The 80 articles were published in a total of 66 journals. It is worth noting that the researchers listed in Table 1 published their work in such journals as International Journal of Human Resource Management, Annals of Operations Research, Gender in Management, and International Journal of Production Economics. These journals are not the most productive in NCSD (Table 2), but are ranked high in terms of the "number of citations per article" (e.g. this score for Journal of Human Resource Management was

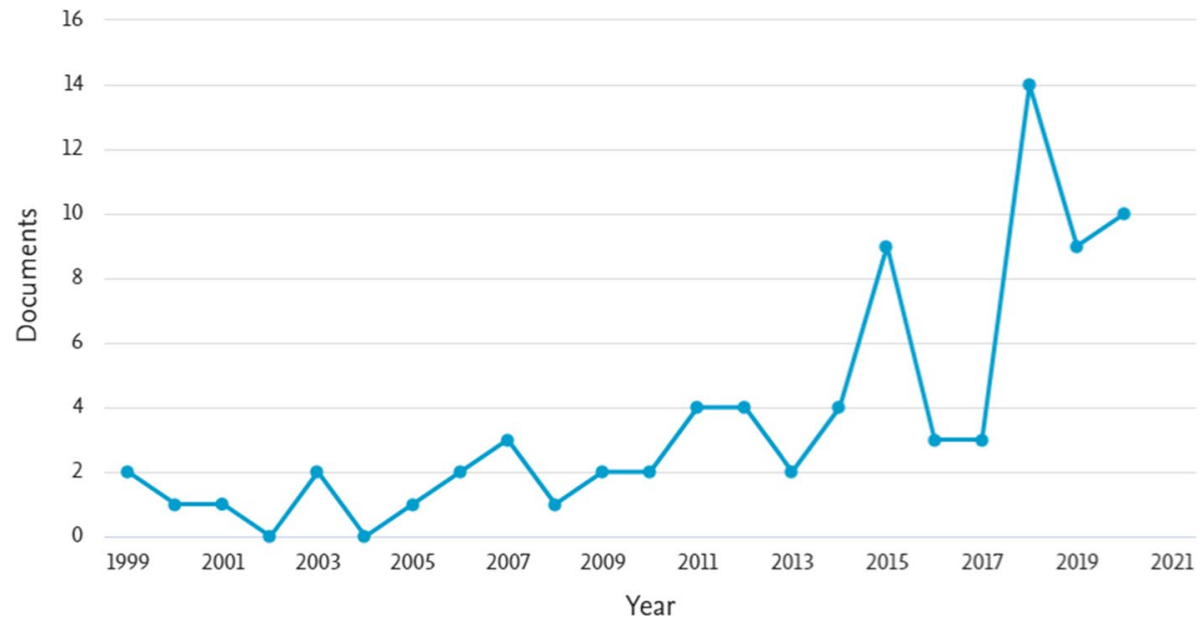

Fig. 2 Number of publications from 1999 to 2020 indexed in Scopus 


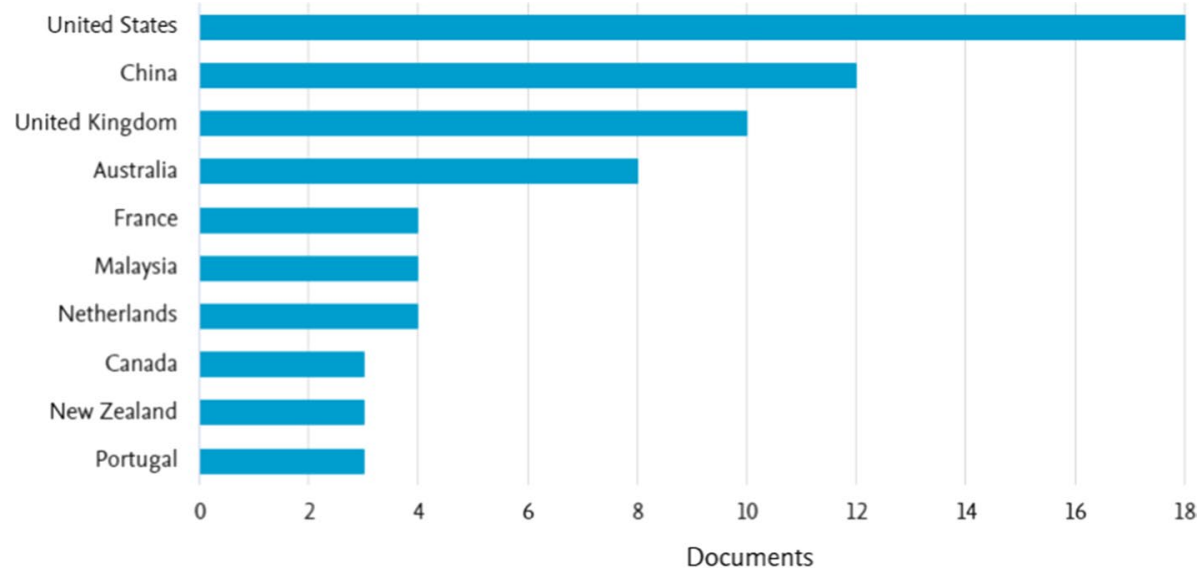

Fig. 3 Number of publications indexed in Scopus, by selected countries

Table 2 The most productive journals in the sample

\begin{tabular}{llcll}
\hline Title of the journal & $\begin{array}{l}\text { Num- } \\
\text { ber of } \\
\text { articles }\end{array}$ & $\begin{array}{l}\text { Number of } \\
\text { citations } \\
\text { received }\end{array}$ & $\begin{array}{l}\text { Number of } \\
\text { citation per } \\
\text { article }\end{array}$ & $\begin{array}{l}\text { Percent of citations } \\
\text { in the sample (\%) }\end{array}$ \\
\hline Sustainability (Switzerland) & 4 & 52 & 13.00 & 3.79 \\
Business Strategy and the Environment & 3 & 54 & 18.00 & 3.94 \\
Social Responsibility Journal & 3 & 25 & 8.33 & 1.82 \\
Emerald Emerging Markets Case Studies & 2 & 1 & 0.50 & 0.07 \\
International Business Review & 2 & 90 & 45.00 & 6.56 \\
Journal of Construction Engineering & 2 & 9 & 4.50 & 0.66 \\
$\quad$ and Management & 2 & 121 & 60.50 & 8.83 \\
Journal of Transport Geography & 2 & 26 & 13.00 & 1.90 \\
Management Decision & 2 & 6 & 3.00 & 0.44 \\
PLoS ONE & 2 & 52 & 26.00 & 3.79 \\
Sustainable Development & 2 & & & \\
\hline
\end{tabular}

92.00). However, the highest number of citations per article was achieved by the Journal of International Financial Management and Accounting because this journal published only one paper the above-mentioned most cited one which received 193 citations.

As Table 2 shows, only ten journals published two or more of the articles. Among them, Sustainability published four manuscripts, the maximum number of articles during the study period, 1999-2020. The high number of journals active in publishing articles suggests that different points of view have been presented to diverse audiences.

The journal titles presented in Table 2 often reflect the scope of a given journal. Additionally, Scopus categorized all the papers according to the research areas. The most represented research areas were Business Management and Accounting $26.1 \%$ of the publications were assigned to this area) and Economics (8.5\% of publications were assigned to this area). 


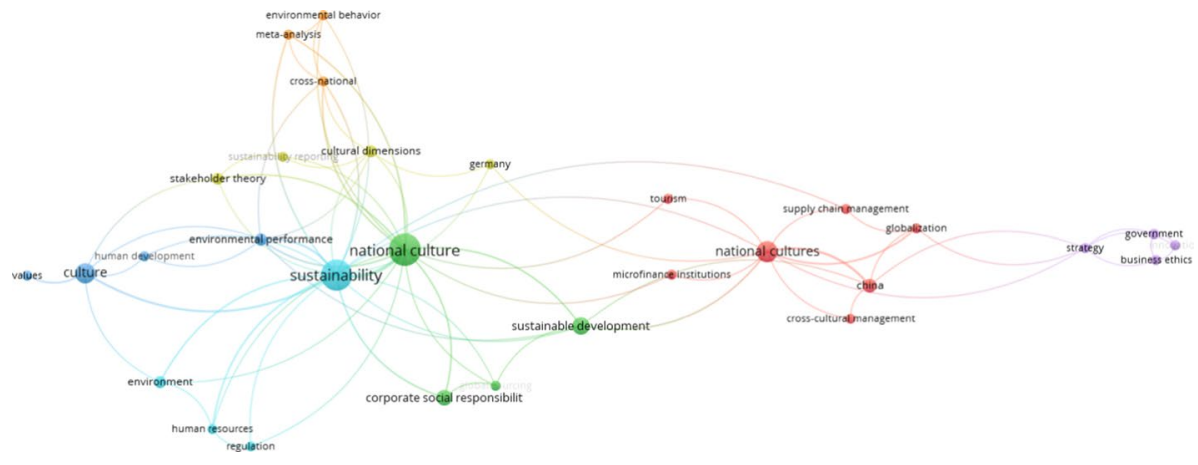

Fig. 4 The keyword network map based on searches in Scopus, made in VOSViewer

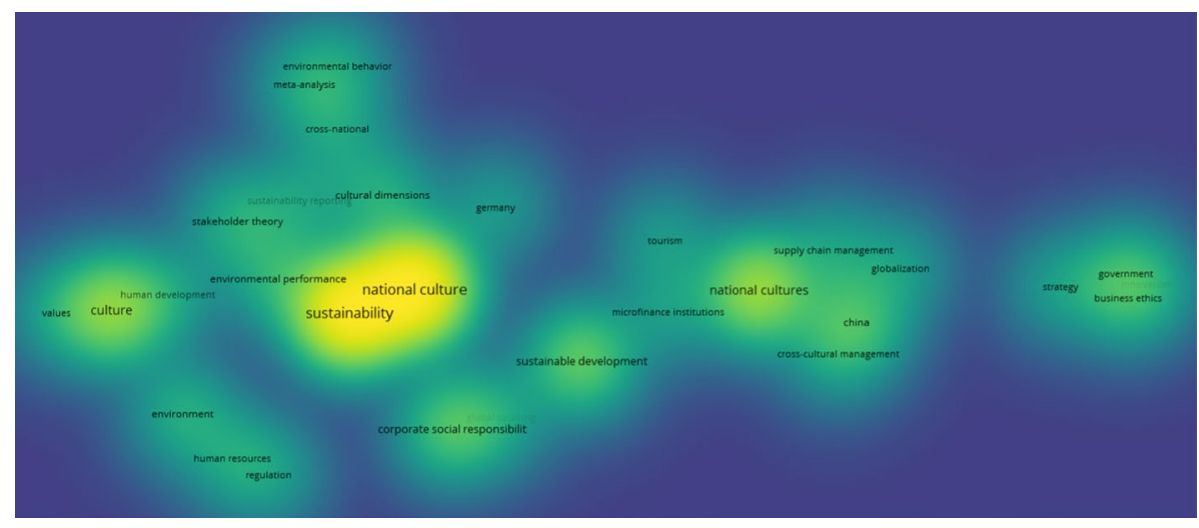

Fig. 5 The density map of clusters based on searches in Scopus, made in VOSViewer

\subsection{The outcomes of keywords network analysis}

An analysis of networks of keywords (Fig. 4) covering clusters sometimes allows internally consistent areas or even research topics to be identified. In turn, an analysis of a density map (Fig. 5) helps to identify less explored topics that may constitute promising areas for further research and development.

Cluster 1 includes such keywords as "China," "cross-cultural management," "globalization," "microfinance institutions," "national culture," "supply chain management," and "tourism." Cluster 2 includes such keywords as "corporate social responsibility," "global sourcing," "national culture," and "sustainable development." Cluster 3 consists of such keywords as "culture," "environmental performance," "human development," and "values." Cluster 4 includes the following keywords: "cultural dimensions," "Germany," "stakeholder theory," and "sustainability reporting." Cluster 5 is formed by such keywords as "business ethics," "government," "innovation," and "strategy." Cluster 6 includes four keywords: "environment," "human resources," "regulation," and "sustainability." Finally, Cluster 7 includes the following keywords: "cross-national," "environmental behavior," and "meta-analysis." 
Cluster 1 is the least coherent internally. In Cluster 2, the overlapping of corporate social responsibility (CSR) and sustainable development is noticeable, which may indicate a greater focus on the problem of the social bottom line. Similarly, Cluster 5 includes business ethics, which is often linked with CSR (Harrison et al., 2019). Clusters 2, 3, 6, and 7 cover the research on the environmental bottom line. Cluster 4 highlights the subject of sustainability reporting.

\subsection{Outcomes of in-depth content analysis}

An in-depth content analysis of all the articles in the sample revealed that most of them were devoted to the link between national culture and the environmental bottom line (Table 3). Social sustainability was the second most discussed pillar of sustainability.

An example of a paper focused only on the social bottom line is the work by Thanetsunthorn and Wuthisatian (2018), which analyzed data from 48 countries in the context of social sustainability (CSR activities toward employees). In turn, an interesting work on consumers' environmental behavior was written by Morren and Grinstein (2016); it was a meta-analysis of findings from individual research projects conducted in 28 countries. In turn, Molthan-Hill (2015) examined how managers from the UK and Germany framed economic rationality in the context of environmental issues.

In total, 63 out of the 80 articles were empirical. In 29 research projects there was an analysis of secondary data, such as websites or the results of previous studies and reports (e.g., from government/World Bank/United Nations databases). In terms of research methods, survey was the second most popular (used in 18 articles) and case study the third (used in eight papers). The articles presented the characteristics of individual countries (Patel \& Rayner, 2015) and comparisons between countries, covering between two (e.g., (Molthan-Hill, 2015)) and 71 countries (Shoham et al., 2017). If the authors used typologies of national cultures in their research, they referred to only one of those presented in the Literature Background section, namely, Hofstede's typology.

When it comes to the detailed research topics addressed in the articles in question, it should be stated that they are highly diverse. As stated in the theoretical part of this study, the concept of sustainability can be defined broadly and at various levels, that is, the individual, organizational, and national levels (de Lange et al., 2012). Many constructs (phenomena or research areas) can be assigned to each of the aforementioned levels. Certain relationships can occur between these constructs and national culture. National culture can be adopted as the only variable studied in a research project or as one of many variables. In-depth content analysis revealed that the subject of reporting sustainability practices or results was the most numerous (13 papers) (Cluster 4$)$. This reporting is also closely related to the features of national culture. However, the authors did not always examine a

Table 3 Pillars of sustainability discussed in the articles

\begin{tabular}{ll}
\hline $\begin{array}{l}\text { Element of TBL discussed in } \\
\text { the paper }\end{array}$ & $\begin{array}{l}\text { Percentage of articles in the sample } \\
\text { with the given bottom line discussed } \\
(\%)\end{array}$ \\
\hline Economic & 21.25 \\
Environmental & 38.75 \\
Social & 36.25 \\
All elements of TBL & 10 \\
\hline
\end{tabular}


complex set of information reported by companies. For example, Gallén and Peraita (2018) analyzed Global Reporting Initiative (GRI) reports, including environmental and social indicators from 44 countries. In turn, Gallego-Álvarez and Ortas (2017) focused only on the environmental bottom line in the GRI reports from 59 countries.

The papers also dealt with topics presented in the keyword networks (Cluster 1), such as supply chain management (e.g., its social aspects in the context of Brazilian culture were discussed by Jabbour et al., (2020)), tourism (the habits of tourists as part of the national culture, the issue of environmentally sustainable tourism (e.g., Pegas et al. (2015)), and particular businesses (microfinance institutions with the focus on economic sustainability) (e.g., Kittilaksanawong and Zhao (2018) or Zainuddin et al. (2020)).

In-depth analysis of all articles allowed other topics which were missing from the keyword networks to be identified, such as education (e.g., Wang and Chiou (2018) assumed that pro-environmental education is evidence of green national culture), infrastructure projects (e.g., public transport in the context of environmental and economic sustainability (Kaminsky, 2018)), and cross-national online playing (as a tool of increasing environmental sustainability (Sims Bainbridge, 2010)).

At this point, it is worth emphasizing yet again that some articles are based on research that covers the specifics of one or two countries. In the case studies on only one country, the national features are considered or further research is planned that would take into account various dimensions of culture (e.g., Kontic \& Kontic 2012). Moreover, the remaining topics mentioned above are focused, to different extents, on combining sustainable development with national culture and on the individual elements of the TBL (similarly to the articles on reporting). For example, Sunil et al. (2020) did not analyze the relationship between national culture and the individual elements of the TBL concept. They only stated that national culture impacts the performance of international joint ventures in terms of sustainable development.

As a result of the in-depth content analysis of all articles in the sample, the author identified only eight articles which holistically approached the concept of sustainable development. The findings are presented in the next section.

\subsection{State of art presented in articles devoted to the problem of relationship between national culture and sustainability treated holistically}

Ho and Taylor (2007) investigated TBL disclosures of companies located in Japan and the USA with the use of Hofstede's cultural typology (the basic version that includes four cultural dimensions). They found that the extent of overall social, environmental, and economic reporting was higher for the Japanese firms. The environmental bottom line was the key issue being reported. This finding was explained with the use of two of the four cultural dimensions: uncertainty avoidance and individualism/collectivism. Higher levels of uncertainty avoidance and collectivism are associated with more involvement in proenvironmental actions. They also found that the extent of reporting of sustainability-related data decreased as a firm's profitability increases. In turn, higher liquidity means less TBL disclosure.

Vachon (2010) also used four dimensions from Hofstede's cultural typology. His analysis of sustainability reports from companies located in 55 countries revealed that higher power distance was reflected in fewer corporate environmental practices. A higher level of uncertainty avoidance was linked with lower levels of green and social activities. More individualism was reflected in a higher degree of sustainable development practices, which 
contradicts research conducted by Ho and Taylor (2007). Although this author also discussed the environmental bottom line with the use of GDP per capita, he did not directly analyze the relationship between culture and economic performance. He found that economic performance was positively and significantly related to other sustainability-oriented indicators, apart from fair labor practices, which is one of the symptoms of the social bottom line. Vitolla et al. (2019) examined the quality of integrated reporting of social, environmental, economic, and governance issues in the context of national cultures. They found that lower power distance and higher uncertainty avoidance, femininity, collectivism, and restraint led to better-quality integrated reports.

Meng et al. (2018) focused on the sustainability of infrastructure construction projects. They found that lower power distance was reflected in better resource allocation (economic bottom line) and natural environment protection. High individualism helped the projects to achieve good results in the social aspect of sustainability. Low masculinity contributed to improving the social bottom line. The higher the level of uncertainty avoidance, the more improvement there was in the environmental bottom line. Long-term orientation was positively correlated with all aspects of infrastructure sustainability.

Mubarak (2006) took up the problem of differences between Egyptian and UAE companies in auditing sustainable development reports. In both countries, various sustainable development indicators are measured because of regulations, but they are not audited. The social performance reporting takes place more often in the UAE than in Egypt (there was a significant difference between the two countries). In Egypt a country with higher power distance the most significant factor for TBL reporting was law enforcement, whereas in the UAE ISO and business excellence were more influential.

Sörensson et al. (2019) adopted Hofstede's typology of cultures (in its extended form, with six cultural dimensions) as did many other researchers. The results of their research show that all companies present a rather similar scope of information as far as the economic aspect of sustainability is concerned. At the same time, they focused more on information related to the environmental bottom line than the social one. A lower level of cultural masculinity was reflected in focusing on equality issues in Northern European countries. In France, issues related to industrial relations were more important than in other countries. The authors linked this fact to a high degree of power distance. In turn, high scores in the dimension of indulgence/restraint impacted the way of enjoying life, thus increasing reporting in terms of good working conditions. High levels of uncertainty avoidance influenced reporting practices as well. Companies from such national cultures reported more formal environmental certifications. The long-term approach in this research was associated more with company size than cultural features.

In-depth content analysis can lead to the identification of papers which discuss more specific topics and simultaneously focus on cultural differences and sustainable development. For example, Braithwaite et al. (2020) analyzed the performance of health systems in 35 countries. They revealed that low power distance, individualism, uncertainty avoidance, and indulgence yield better performance related to the TBL. Finally, Thornton et al. (2013) analyzed supplier selection practices in three culturally different countries, the USA, China, and the UAE, and found that the national culture did not differentiate the effects on financial performance of sustainability-related initiatives undertaken within the selection process.

Table 4 presents a summary of the findings from papers which used Hofstede's cultural typology and associated SD with the TBL approach. As presented above, in two papers national culture was recognized as a factor which did not impact economy-related issues. Although other papers based on Hofstede's typology also explored the economic 
Table 4 Summary of findings from papers devoted to the relationship between national culture and sustainability, treated holistically

\begin{tabular}{llll}
\hline $\begin{array}{l}\text { Independent variable } \\
\text { (cultural dimension) }\end{array}$ & $\begin{array}{l}\text { The type of bottom line } \\
\text { (dependent variable) }\end{array}$ & Type of impact & Authors \\
\hline Uncertainty avoidance & Environmental & Positive & Ho and Tylor, Meng et al \\
& $\begin{array}{l}\text { Environmental } \\
\text { Social }\end{array}$ & Negative & Vachon \\
& All aspects of sustainability & Positive & Vachon \\
& All aspects of sustainability & Positive & Sörensson et al \\
Eollectivism & Environmental & Positive & Ho and Tylor \\
& All aspects of sustainability & Negative & Vachon \\
& All aspects of sustainability & Positive & Vitolla et al., Braithwaite et al \\
& Social & NEGATIVE & Meng et al \\
Power Distance & Environmental & Negative & Vachon, Meng et al \\
& All aspects of sustainability & Positive & Vitolla et al \\
& Economic & Negative & Meng et al \\
& All aspects of sustainability & Negative & Mubarak, Braithwaite et al \\
Femininity & Social & Positive & Sörensson et al \\
& All aspects of sustainability & Positive & Vitolla et al., Braithwaite et al \\
& Social & Positive & Sörensson et al \\
& Social & Positive & Meng et al., Sörensson et al \\
& All aspects of sustainability & Positive & Meng et al \\
\hline
\end{tabular}

bottom line, they did not present detailed relationships between cultural dimensions and this aspect. The economic bottom line was included in the statements that national culture influences all of the bottom lines.

\section{Discussion}

As mentioned above, there is no doubt that national culture impacts sustainable development in terms of goals, means, and results. Taking into account the first research question, one can state that scholarly interest in the NCSD research field is growing. The scientific structure is formed by 80 articles which come mostly from the USA, Australia, and Western European countries. The sample includes 63 empirical papers, which were based mostly on analyses of secondary data.

To answer the second research questions, which refers to problems addressed in the analyzed papers, seven clusters of keywords were identified and in-depth content analysis was provided. Cluster 1 came out to be the least coherent internally. In-depth content analysis revealed that there were numerous detailed problems (topics) addressed in the papers in question. Moreover, national culture in some papers was treated only as a background not as an examined variable. Cluster 2 shows the overlap of CSR and SD problems. Clusters 2, 3,6 , and 7 cover the research on the environmental bottom line.

Cluster 4 highlights the subject of sustainability reporting. In-depth content analysis revealed that the most popular topic identified in 13 papers was the relationship between cultural dimensions and practices related to reporting on sustainability. Although 
sustainable development reports could represent a useful part of the company information system, helping to communicate with both external and internal stakeholders, such reporting is a practice used more by large companies. Part of the research presented in this article (e.g., Jennifer Ho and Taylor (2007) or Sörensson et al. (2019)) was based solely on the reports originating from large companies. As Gray stated, "reporting almost never offers a complete picture of organizational activity, [...and] is exceptionally selective, sustainability reporting, despite protestations to the contrary, is yet to address sustainability and accountability is not discharged. The lack of regulation has been identified as a barrier to improving quality within the accountability literature arguing that while sustainability reporting remains a voluntary process, companies will not discharge accountability" (Gray, 2007, p. 181).

Looking at the development of the sustainability concept, one can state that initially environmental sustainability issues dominated in the literature (Von Weizsaecker \& Wijkman, 2018). However, the concept of CSR was developed at the same time (Carroll, 1999). In the past the term "corporate sustainability" was used as a synonym of CSR (Hahn \& Scheermesser, 2006). The evolution of general interest in SD corresponds with the findings of this study in terms of the bottom lines which are most discussed in the literature. National culture is mostly linked with issues related to the environmental bottom line. In second place, relationships between national culture and the social aspects of SD are discussed. Only eight papers addressed all elements of the TBL together. The above constitutes the answer to the third research question.

The term "triple bottom line" emphasizes that the three aspects of sustainability should be analyzed jointly (Elkington, 2004). Detailed research findings on the relationships between national culture and a comprehensive approach to sustainable development (see: the fourth research question) are presented in Sect. 4.4. At this point it is worth emphasizing that papers discussing the linkage between national culture and all elements of the TBL even if they make use of company sustainability reports are rare and based on different research assumptions (different versions of Hofstede's typology, different numbers of countries in the analysis, and different types of reports/data sources). For example, Vachon (2010) analyzed data from 55 countries, but did not list them. Subsequent research projects are methodologically different from the previous ones.

Both in the initial research sample and in the articles discussing the relationships between national culture and sustainability analyzed from the TBL perspective, the authors applied mainly the cultural typology authored by Hofstede. There is a growing criticism of this typology (Williamson, 2002), but the simplicity of its dimensions and use (easy access to the data set) is likely responsible for its popularity (Chanchani \& Theivananthampillai, 2009).

Morren and Grinstein (2016) presented in their literature review that people from individualistic countries behave environmentally more than people from collectivistic countries. In turn, Adedeji et al. (2017) mentioned in their literature review that collectivism and power distance dimensions of culture impact positively on initiatives related to financial bottom line. These two findings were also confirmed by Zheng et al. (2021) who stated that collectivism is a driving force of the economic development whereas individualism secures environmental protection. This study shows that the impact of cultural dimensions is not so "black" or "white". The inconsistencies in the results obtained by different researchers are visible in Table 4. This is in line with finding presented by Tata and Prasad (2015) in their conceptual paper which reviewed previous studies on the association between national culture and organizational sustainability initiatives. Furthermore, the 
results from previous research are not universal because they are valid for a given moment and for the populations under study.

The above presented considerations provide valuable material for answering the fifth research question. The research directions for future research (being the answer to this research question) are listed below.

\subsection{Recommendation 1: methodological diversity, rigor, and continuity}

It is necessary to improve the scientific quality of research systems. The authors of the studies included herein suggested that more diverse methods should be adopted within NCSD research. For example, Thornton et al. (2013) postulated the use of qualitative methods in the form of case studies. Another interesting avenue for future research is to combine the research approach based on secondary data with field research (surveys and case studies).

Researchers used a one-time dataset to determine the relationship between national culture and sustainable development. Culture is a dynamic phenomenon; it changes and evolves with the passage of time (Lee \& Choi, 2006). Data and reports change, as do human activities. Therefore, longitudinal data are needed to show the chronological sequencing of the variables. Since secondary data (reports and cultural scores of countries) are publicly available, researchers should be able to analyze the chronological sequencing of the variables under study (Oh \& Park, 2020).

Although Hofstede's typology is the easiest to apply (Chanchani \& Theivananthampillai, 2009), it would be valuable to use other cultural typologies. Researchers may attempt to study a combination of different cultural typologies. For example, Hofstede's typology could be combined with Triandis's typology for an in-depth investigation of people's individualistic/collectivist orientations within a culture. The development of new, more robust typologies is also a scientific challenge (Chanchani \& Theivananthampillai, 2009).

In addition, there is no consistency in the measures used in subsequent articles (different reports use different versions of Hofstede's typology). Therefore, future studies should explore the NCSD field with a consistent set of measures.

\subsection{Recommendation 2: research topics}

Culture should be "the central dimension of sustainable development and should be integrated fully into the economic, social, and environmental dimensions" (Opoku, 2015, p. 42). This study shows that linking national culture with holistically treated sustainable development is a rarely explored research area. More research fulfilling the above-presented methodological requirements is needed. Moreover, the analysis of the density map of keywords provides ideas on topics which may be developed further. For example, globalization is a less popular keyword, but globalization enhances cultural identity. Therefore, in future studies it is worth examining how cultural globalization is advancing in the context of sustainability-related cultural values.

\subsection{Recommendation 3: cooperation and stimulation of other regions}

Since the interest in NCSD is growing and there are many methodological challenges, there is much room for scientific development for researchers from those countries which are not among the most productive regions. Many foreign direct investments are located 
in post-communist economies (Salahodjaev et al., 2016) (including Central and Eastern Europe), and transforming the cultures of post-communist countries (e.g., the Visegrad Group countries) in the context of sustainability is a topic worthy of further exploration (Sulich \& Sołoducho-Pelc, 2021). As this study shows, many papers have been written by few authors, but there is a lack of cooperation between the most productive authors. Cooperation between researchers (e.g., more and less experienced, from West and East) is one way to speed up scientific process.

\section{Contributions and implications}

\subsection{Theoretical contributions}

This study contributes to the field of knowledge by filling a gap in the literature reviews that link the issue of national culture with sustainable development. First, the author defined the general NCSD field, stating that research in this field may explore the impact of culture on different levels. The same refers to the issue of the TBL approach adopted. SD may be explored from the perspective of the TBL, including goals, activities, and results, as well as by different levels of their application. The analysis presented herein contributes to the understanding of the composition of the NCSD field in general and the interplay between national culture and SD, treated holistically, which means that all elements of the TBL are analyzed simultaneously. Although some previous studies reviewed different aspects of culture and SD, none of them used the same definition of the research field or were based on the application of both scientometric and in-depth manual analysis. The latter constitutes a methodological contribution of this study.

Several gaps in the NCSD field were identified. Less attention has been paid in the literature to exploring all the pillars of sustainability simultaneously. Although all elements of the TBL are mutually interconnected, the holistic approach to SD implies an integrated examination of economic, environmental, and social issues. This should encourage scientists to provide more comprehensive analysis. Moreover, this study revealed a lack of continuity and cooperation between scientists. A valid synthesis of the findings in the form of generalizations stemming from the papers related to all elements of the TBL concept was impossible in this study due to the fact that they were based on different assumptions. However, the identification of the limits of generalizations is also a scientific contribution (Cooper, 2010).

\subsection{Academic and practical implications}

This article is intended to provide guidelines for scholars in positioning their future research efforts. It presents what has been published in the field of NCSD by indicating the journals' productivity, detailed topics, research methods, and research gaps. Potential authors may use the presented findings as a means to assess the field. Moreover, they may follow the detailed recommendations which are presented in Sect. 5 as the answer to the fifth research question.

As Cummings and Daellenbach (2009) stated, literature reviews are important, not only for advancing an academic field, but also for informing management practice. The analysis of the literature on the subject developed in this study also offers valuable insights for practitioners to better understand how the intellectual structure of NCSD field looks. 
Practitioners may use the scientometric information presented in this study to choose journals as sources of a broader scope of information on the relationships between national culture and sustainable development. Furthermore, it can help them to understand the notion and typologies of national culture and the influence of national culture on sustainable development. It also makes them aware of the discrepancies between the findings of various studies.

Policymakers should be aware that national culture is both the end result of decisions/ policies that have been implemented and an instrument for implementing changes. They should include cultural aspects in decision-making, research, and policy frameworks for sustainable development. Sustainability education programs should also include cultural differences. Furthermore, the inconsistencies in the results obtained by different researchers in terms of the relationship between cultural dimensions and elements of the TBL emphasize that the solutions to sustainability problems are not universal. This finding may encourage policymakers to develop cultural heterogeneity within the nation (Zheng et al., 2021) and measure how it stimulates the overall sustainability. Finally, this study may be utilized as a source of adjusting research policies to funding allocations ( $\mathrm{Gu}, 2004)$.

\section{Conclusions, limitations and future perspectives}

This paper presents a comprehensive review of NCSD. It fills a gap in the literature reviews that link the issue of national culture with sustainable development, particularly by treating sustainability holistically and by using a mixed-method research approach. Based on scientometric data, it demonstrates the growing interest in this field of knowledge (especially in Western countries) and the research productivity in terms of authors and journals. The analysis conducted with the use of VOSViewer as well as the manual in-depth studies revealed a variety of topics in this research field and the empirical methods and cultural typologies used. The results indicate that the literature mostly presents analyses based on different sets of secondary data and focusing especially on certain aspects involved in $\mathrm{SD}$, such as reporting practices. The cultural typology created by Hofstede is the only one used in the analyzed articles. As far as the TBL approach is concerned, most of studies discuss the environmental bottom line, though the author did identify papers which discussed all element of the TBL and synthesized their findings, focusing on the limits of their generalizations.

This study helps to develop a higher level of awareness of the complexity of the NCSD field and motivates scholars to further advance the knowledge in this research domain. There is much room for future research to further expand the line of research discussed in this paper. Three detailed directions for future research were presented above. At this point it is worth describing some limitations of this study which can be overcome in further research.

This literature review presents articles as of the end of 2020. The citation count, one of the measures used in this study, is biased toward a specific date. Further analyses covering newly published papers in the field using the same methodology are required. Additionally, they could include not only articles, but also book chapters and conference papers.

The method of searching the databases may have left some valuable articles out of the sample if their authors did not include the search terms among the keywords, title, or abstract or if the articles are not indexed in the Scopus database. Future lines of research could complete the present study with results obtained from different databases, such as 
Web of Science and Dimensions. Other search parameters (scope of text) may also be extended.

Finally, the analysis was conducted by one author, and thus another limitation is personal bias. In case of multiple authorship, different people contribute directly, working independently, carefully examining each document and comparing their results. This increases the validity of the work (Di Vaio et al., 2020; Vaio et al., 2020). Therefore, it is worth comparing the results of this study with findings from analyses which follow the presented research assumptions but are a product of teamwork.

\section{Appendix}

See Table 5. 


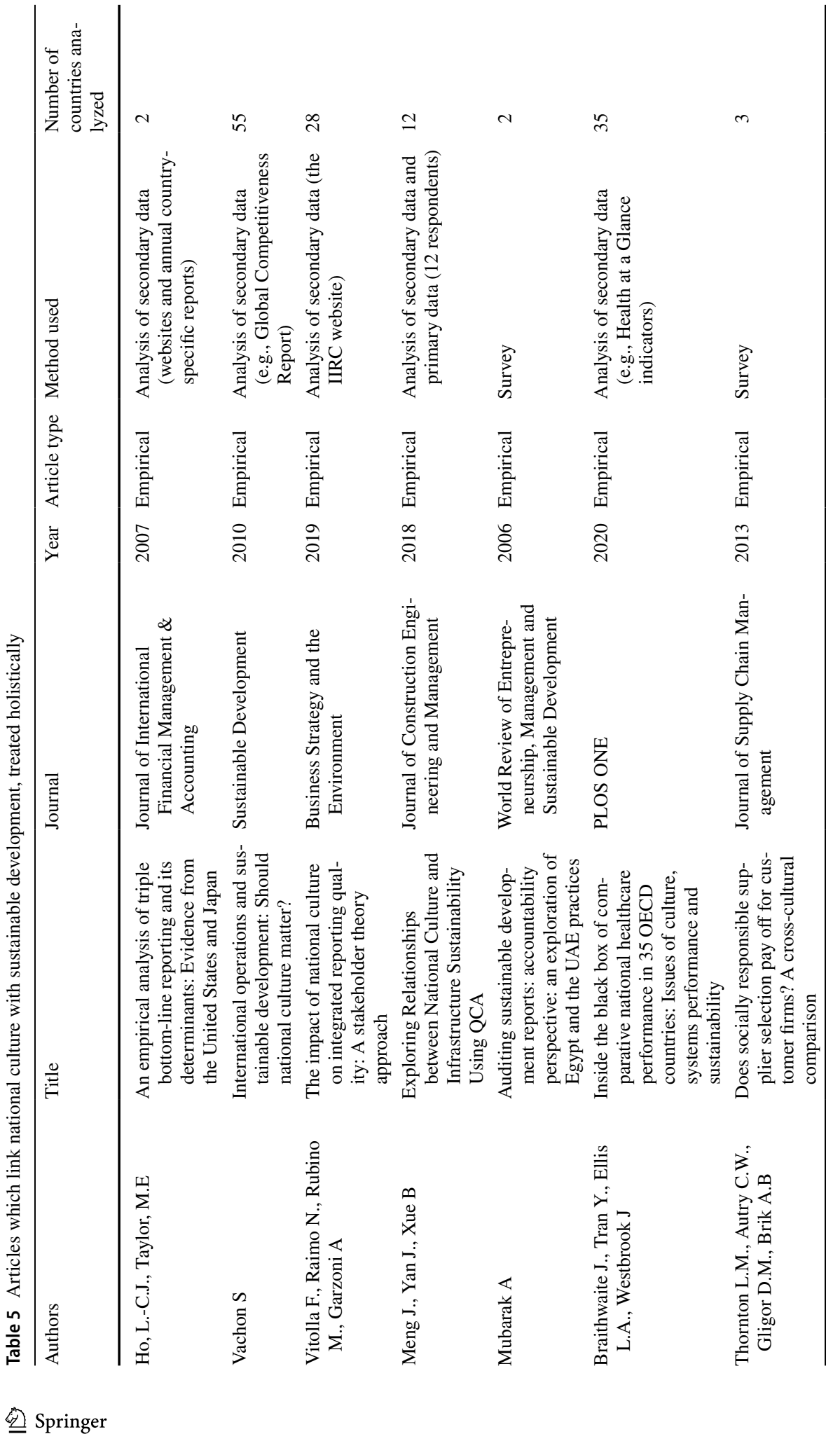




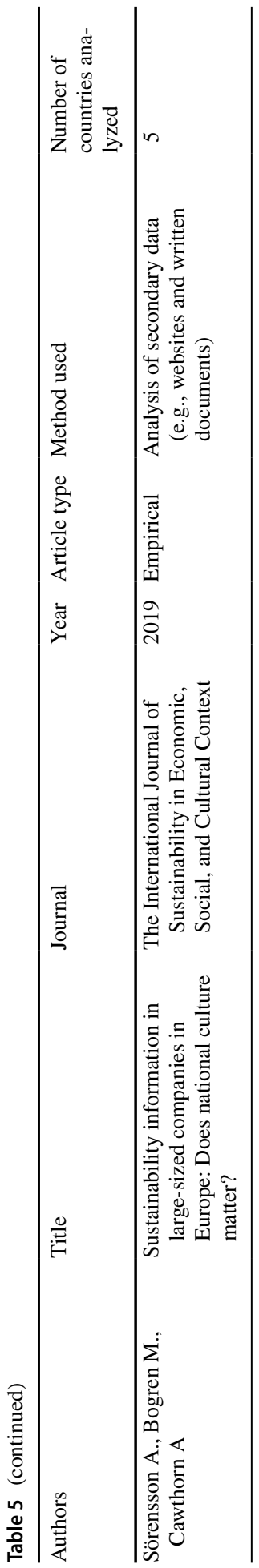


Acknowledgements The author would like to thank the Editors and three anonymous Referees for providing valuable suggestions which contributed to increasing the quality of this article.

Funding The project is financed by the Ministry of Science and Higher Education in Poland under the program "Regional Initiative of Excellence 2019-2022," Project Number 015/RID/2018/19, with a total Funding of 10,721,040.00 PLN.

Data availability Due to the limited length of the article all detailed data are available on request.

\section{Declarations}

Conflict of interest There is no conflict of interest to declare.

Open Access This article is licensed under a Creative Commons Attribution 4.0 International License, which permits use, sharing, adaptation, distribution and reproduction in any medium or format, as long as you give appropriate credit to the original author(s) and the source, provide a link to the Creative Commons licence, and indicate if changes were made. The images or other third party material in this article are included in the article's Creative Commons licence, unless indicated otherwise in a credit line to the material. If material is not included in the article's Creative Commons licence and your intended use is not permitted by statutory regulation or exceeds the permitted use, you will need to obtain permission directly from the copyright holder. To view a copy of this licence, visit http://creativecommons.org/licenses/by/4.0/.

\section{References}

Adedeji, B., Johnson Popoola, O. M., \& San Ong, T. (2017). National culture and sustainability disclosure practices: A literature review. Indian-Pacific Journal of Accounting and Finance, 1(1), 26-48.

Alper, S. (2019). Power distance. In Encyclopedia of personality and individual differences (pp. 1-3). Springer. https://doi.org/10.1007/978-3-319-28099-8_1888-1.

Alvino, F., Di Vaio, A., Hassan, R., \& Palladino, R. (2020). Intellectual capital and sustainable development: A systematic literature review. Journal of Intellectual Capital, 22(1), 76-94. https://doi.org/10. 1108/JIC-11-2019-0259

Alwitt, L. F., \& Pitts, R. E. (1996). Predicting purchase intentions for an environmentally sensitive product. Journal of Consumer Psychology, 5(1), 49-64. https://doi.org/10.1207/s15327663jcp0501_03

Anantatmula, V. S. (2010). Impact of cultural differences on knowledge management in global projects. Vine, 40(3/4), 239-253. https://doi.org/10.1108/03055721011071377

Assunta, D. V., Palladino, R., Pezzi, A., \& Kalisz, D. E. (2021). The role of digital innovation in knowledge management systems: A systematic literature review. Journal of Business Research, 123, 220-231. https://doi.org/10.1016/j.jbusres.2020.09.042

Ayub Khan, M., \& Smith Law, L. (2018). The role of national cultures in shaping the corporate management cultures: A three-country theoretical analysis. In Organizational Culture. IntechOpen. https://doi.org/ 10.5772/intechopen.78051.

Beyers, J. (2017). Religion and culture: Revisiting a close relative. HTS Teologiese Studies/Theological Studies. https://doi.org/10.4102/hts.v73i1.3864

Braithwaite, J., Tran, Y., Ellis, L. A., \& Westbrook, J. (2020). Inside the black box of comparative national healthcare performance in 35 OECD countries: Issues of culture, systems performance and sustainability. PLoS ONE, 15(9), e0239776. https://doi.org/10.1371/journal.pone.0239776

Broman, G. I., \& Robèrt, K.-H. (2017). A framework for strategic sustainable development. Journal of Cleaner Production, 140, 17-31. https://doi.org/10.1016/j.jclepro.2015.10.121

Brundtland, G. H. (Ed.). (1987). Report of the world commission on environment and development: Our common future. Oxford University Press.

Cameron, K. S., Quinn, R. E., DeGraff, J., \& Thakor, A. V. (2006). Competing values leadership: Creating value in organizations. Edward Elgar Publishing.

Camón Luis, E., \& Celma, D. (2020). Circular economy: A review and bibliometric analysis. Sustainability, 12(16), 6381. https://doi.org/10.3390/su12166381

Capobianco-Uriarte, M., De Las, M., Casado-Belmonte, M., Del, P., Marín-Carrillo, G. M., \& Terán-Yépez, E. (2019). A bibliometric analysis of international competitiveness (1983-2017). Sustainability, 11(7), 1877. https://doi.org/10.3390/su11071877 
Carroll, A. B. (1999). Corporate social responsibility. Business \& Society, 38(3), 268-295. https://doi.org/ $10.1177 / 000765039903800303$

Chanchani, S., \& Theivananthampillai, P. (2009). Typologies of culture. SSRN Electronic Journal. https:// doi.org/10.2139/ssrn. 1441609

Chen, G., \& Xiao, L. (2016). Selecting publication keywords for domain analysis in bibliometrics: A comparison of three methods. Journal of Informetrics, 10(1), 212-223. https://doi.org/10.1016/j.joi.2016. 01.006

Chen, J. C., \& Roberts, R. W. (2010). Toward a more coherent understanding of the organization-society relationship: A theoretical consideration for social and environmental accounting research. Journal of Business Ethics, 97(4), 651-665. https://doi.org/10.1007/s10551-010-0531-0

Cialdini, R. B., Kallgren, C. A., \& Reno, R. R. (1991). A Focus Theory of Normative Conduct: A Theoretical Refinement and Reevaluation of the Role of Norms in Human Behavior (pp. 201-234). https://doi. org/10.1016/S0065-2601(08)60330-5.

Clay Whybark, D. (1997). GMRG survey research in operations management. International Journal of Operations \& Production Management, 17(7), 686-696. https://doi.org/10.1108/014435797101756 00

Cooper, H. (2010). Research synthesis and meta-analysis: a step-by-step approach. Applied Social Research Methods Series, v. 2. SAGE Publications.

Correia, M. S. (2019). Sustainability. International Journal of Strategic Engineering, 2(1), 29-38. https:// doi.org/10.4018/IJoSE.2019010103

Crane, A., Matten, D., \& Moon, J. (2008). Corporations and Citizenship. Cambridge University Press. https://doi.org/10.1017/CBO9780511488542

Cummings, S., \& Daellenbach, U. (2009). A guide to the future of strategy? Long Range Planning, 42(2), 234-263. https://doi.org/10.1016/j.lrp.2008.12.005

Dangelico, R. M., Fraccascia, L., \& Nastasi, A. (2020). National culture's influence on environmental performance of countries: A study of direct and indirect effects. Sustainable Development, 28(6), 17731786. https://doi.org/10.1002/sd.2123

de Lange, D. E., Busch, T., \& Delgado-Ceballos, J. (2012). Sustaining sustainability in organizations. Journal of Business Ethics, 110(2), 151-156. https://doi.org/10.1007/s10551-012-1425-0

Del Giudice, M., Di Vaio, A., Hassan, R., \& Palladino, R. (2021). Digitalization and new technologies for sustainable business models at the ship-port interface: A bibliometric analysis. Maritime Policy \& Management. https://doi.org/10.1080/03088839.2021.1903600

Di Vaio, A., Palladino, R., Hassan, R., \& Alvino, F. (2020). Human resources disclosure in the EU Directive 2014/95/EU perspective: A systematic literature review. Journal of Cleaner Production. https://doi. org/10.1016/j.jclepro.2020.120509

Di-Vaio, A., Palladino, R., Hassan, R., \& Escobar, O. (2020). Artificial intelligence and business models in the sustainable development goals perspective: A systematic literature review. Journal of Business Research, 121, 283-314. https://doi.org/10.1016/j.jbusres.2020.08.019

Dörgő, G., Sebestyén, V., \& Abonyi, J. (2018). Evaluating the interconnectedness of the sustainable development goals based on the causality analysis of sustainability indicators. Sustainability, 10(10), 3766. https://doi.org/10.3390/su10103766

Dubey, R., Gunasekaran, A., Childe, S. J., Papadopoulos, T., Hazen, B., Giannakis, M., \& Roubaud, D. (2017). Examining the effect of external pressures and organizational culture on shaping performance measurement systems (PMS) for sustainability benchmarking: Some empirical findings. International Journal of Production Economics, 193, 63-76. https://doi.org/10.1016/j.ijpe.2017.06.029

Elkington, J. (1997). Cannibals with forks: the triple bottom line of 21st century business. John Wiley and Sons.

Elkington, J. (2004). Enter the triple bottom line. In A. Henriques \& J. Richardson (Eds.), The triple bottom line: Does it all add up? (pp. 1-16). Earthscan.

Ellis, R. J., \& Thompson, F. (1997). Culture and the environment in the Pacific Northwest. American Political Science Review, 91(4), 885-897. https://doi.org/10.2307/2952171

Ettlie, J. E. (2009). Quality, technology, and global manufacturing. Production and Operations Management, 6(2), 150-166. https://doi.org/10.1111/j.1937-5956.1997.tb00423.x

Ferasso, M., \& Cherobim, A. P. M. S. (2017). Bibliometric analysis of international researches on innovation metrics. International Journal of Bibliometrics in Business and Management. https://doi. org/10.1504/ijbbm.2017.10003440

Fishbein, M. (1963). An investigation of the relationships between beliefs about an object and the attitude toward that object. Human Relations, 16(3), 233-239. https://doi.org/10.1177/0018726763 01600302 
Fiske, A. P. (1992). The four elementary forms of sociality: Framework for a unified theory of social relations. Psychological Review, 99(4), 689-723. https://doi.org/10.1037/0033-295X.99.4.689

Gallego-Álvarez, P. I., \& Ortas, P. E. (2017). Corporate environmental sustainability reporting in the context of national cultures: A quantile regression approach. International Business Review, 26(2), 337-353. https://doi.org/10.1016/j.ibusrev.2016.09.003

Gallén, M. L., \& Peraita, C. (2018). The effects of national culture on corporate social responsibility disclosure: A cross-country comparison. Applied Economics, 50(27), 2967-2979. https://doi.org/ $10.1080 / 00036846.2017 .1412082$

Genç, K. Y. (2013). Culture as a strategic resource for organizations and an assessment on cultures of turkish large firms. Procedia: Social and Behavioral Sciences, 75, 525-531. https://doi.org/10. 1016/j.sbspro.2013.04.057

Gray, R. (2007). Taking a long view on what we now know about social and environmental accountability and reporting. Issues In Social And Environmental Accounting, 1(2), 169. https://doi.org/ 10.22164 isea.v1i2.13

Gu, Y. (2004). Global knowledge management research: A bibliometric analysis. Scientometrics, 61(2), 171-190. https://doi.org/10.1023/B:SCIE.0000041647.01086.f4

Guo, Q., Liu, Z., Li, X., \& Qiao, X. (2018). Indulgence and long term orientation influence prosocial behavior at national level. Frontiers in Psychology. https://doi.org/10.3389/fpsyg.2018.01798

Hahn, T., \& Scheermesser, M. (2006). Approaches to corporate sustainability among German companies. Corporate Social Responsibility and Environmental Management, 13(3), 150-165. https:// doi.org/10.1002/csr.100

Harrison, D. E., Ferrell, O. C., Ferrell, L., \& Hair, J. F., Jr. (2019). Corporate social responsibility and business ethics: Conceptualization, scale development and validation. Journal of Product \& Brand Management, 29(4), 431-439. https://doi.org/10.1108/JPBM-11-2018-2113

Henriksson, H., \& Weidman Grunewald, E. (2020). Society as a Stakeholder. In Sustainability leadership (pp. 173-199). Springer. https://doi.org/10.1007/978-3-030-42291-2_10.

Hofstede, G., Hofstede, G. J., \& Minkov, M. (2010). Cultures and organizations: Software of the mind: Intercultural operation and its importance for survival (3rd ed.). MCGraw-Hil.

Hofstede, G. (1984). Cultural dimensions in management and planning. Asia Pacific Journal of Management, 1(2), 81-99. https://doi.org/10.1007/BF01733682

Hofstede, G. (1991). Culture and organizations: Software of the Mind. MCGraw-Hill.

Hofstede, G. (2016). Masculinity at the national cultural level. APA handbook of men and masculinities (pp. 173-186). American Psychological Association.

Hofstede, G., \& Bond, M. H. (1988). The Confucius connection: From cultural roots to economic growth. Organizational Dynamics, 16(4), 5-21. https://doi.org/10.1016/0090-2616(88)90009-5

Hopwood, B., Mellor, M., \& O’Brien, G. (2005). Sustainable development: Mapping different approaches. Sustainable Development, 13(1), 38-52. https://doi.org/10.1002/sd.244

Islam. (2013). The effect of national culture on total quality management and organizational performance. American Journal of Applied Sciences, 10(10), 1191-1200. https://doi.org/10.3844/ajassp. 2013.1191.1200

Jabbour, C. J. C., Janeiro, R. C., de Sousa Jabbour, A. B. L., Junior, J. A. G., Salgado, M. H., \& Jugend, D. (2020). Social aspects of sustainable supply chains: Unveiling potential relationships in the Brazilian context. Annals of Operations Research, 290(1-2), 327-341. https://doi.org/10.1007/ s10479-017-2660-7

Jennifer Ho, L.-C., \& Taylor, M. E. (2007). An empirical analysis of triple bottom-line reporting and its determinants: evidence from the united states and Japan. Journal of International Financial Management \& Accounting, 18(2), 123-150. https://doi.org/10.1111/j.1467-646X.2007.01010.X

Jones, M. L. (2007). Hofstede: Culturally questionable? https://ro.uow.edu.au/cgi/viewcontent.cgi?artic $1 \mathrm{e}=1389 \&$ context $=$ commpapers.

Kaminsky, J. A. (2018). National culture shapes private investment in transportation infrastructure projects around the globe. Journal of Construction Engineering and Management, 144(2), 04017098. https://doi.org/10.1061/(ASCE)CO.1943-7862.0001416

Khan, A., Hassan, M. K., Paltrinieri, A., Dreassi, A., \& Bahoo, S. (2020). A bibliometric review of takaful literature. International Review of Economics \& Finance, 69, 389-405. https://doi.org/10.1016/j.iref. 2020.05.013

Kittilaksanawong, W., \& Zhao, H. (2018). Does lending to women lower sustainability of microfinance institutions? Moderating role of national cultures. Gender in Management: An International Journal, 33(3), 187-202. https://doi.org/10.1108/GM-11-2015-0098 
Klarin, T. (2018). The concept of sustainable development: from its beginning to the contemporary issues. Zagreb International Review of Economics and Business, 21(1), 67-94. https://doi.org/10.2478/ zireb-2018-0005

Klassen, R., \& Angell, L. (1998). An international comparison of environmental management in operations: The impact of manufacturing flexibility in the US and Germany. Journal of Operations Management, 16(2), 177-194.

Kontic, L., \& Kontic, J. (2012). Sustainability and readiness for change: Insights from a banking case study in Serbia. Amfiteatru Economic, 14(32), 537-548.

Kroesen, M., Handy, S., \& Chorus, C. (2017). Do attitudes cause behavior or vice versa? An alternative conceptualization of the attitude-behavior relationship in travel behavior modeling. Transportation Research Part a: Policy and Practice, 101, 190-202. https://doi.org/10.1016/j.tra.2017.05.013

Lee, W.-N., \& Choi, S. M. (2006). The role of horizontal and vertical individualism and collectivism in online consumers' responses toward persuasive communication on the web. Journal of ComputerMediated Communication, 11, 317-336. https://doi.org/10.1111/j.1083-6101.2006.00015.x

Lewis, M. O., Mathiassen, L., \& Rai, A. (2011). Scalable growth in IT-enabled service provisioning: A sensemaking perspective. European Journal of Information Systems, 20(3), 285-302. https://doi.org/ 10.1057/ejis.2011.5

Mansaray, H. E., \& Mansaray, H. E., Jr. (2020). The Connection between national culture and organizational culture: A literature review. Britain International of Humanities and Social Sciences (BIoHS) Journal., 2(1), 179-189. https://doi.org/10.33258/biohs.v2i1.168

Meng, J., Yan, J., \& Xue, B. (2018). Exploring relationships between national culture and infrastructure sustainability using QCA. Journal of Construction Engineering and Management, 144(9), 04018082. https://doi.org/10.1061/(ASCE)CO.1943-7862.0001463

Milne, B. T. (2017). Elements of a holistic theory to meet the sustainability challenge. Systems Research and Behavioral Science, 34(5), 553-563. https://doi.org/10.1002/sres.2493

Minkov, M., \& Hofstede, G. (2012). Is national culture a meaningful concept? Cross-Cultural Research, 46(2), 133-159. https://doi.org/10.1177/1069397111427262

Molthan-Hill, P. (2015). Making the business case? Critical Perspectives on International Business, 11(1), 72-91. https://doi.org/10.1108/cpoib-07-2012-0033

Mongeon, P., \& Paul-Hus, A. (2016). The journal coverage of web of science and Scopus: A comparative analysis. Scientometrics, 106(1), 213-228. https://doi.org/10.1007/s11192-015-1765-5

Morren, M., \& Grinstein, A. (2016). Explaining environmental behavior across borders: A meta-analysis. Journal of Environmental Psychology, 47, 91-106. https://doi.org/10.1016/j.jenvp.2016.05.003

Mubarak, A. (2006). Auditing sustainable development reports: Accountability perspective-An exploration of Egypt and the UAE practices. World Review of Entrepreneurship, Management and Sustainable Development, 2(3), 211. https://doi.org/10.1504/WREMSD.2006.009889

Oh, J., \& Park, J. (2020). An integrative review of SHRM research in South Korea: Current status and future directions. Employee Relations: The International Journal, 43(1), 155-175. https://doi.org/10.1108/ ER-09-2019-0365

Opoku, A. (2015). The role of culture in a sustainable built environment. In A. Chiarini (Ed.), Sustainable operations management (pp. 37-52). Springer.

Owusu Ansah, M., \& Louw, L. (2019). The influence of national culture on organizational culture of multinational companies. Cogent Social Sciences, 5(1), 1623648. https://doi.org/10.1080/23311886.2019. 1623648

Pagell, M., Katz, J. P., \& Sheu, C. (2005). The importance of national culture in operations management research. International Journal of Operations \& Production Management, 25(4), 371-394. https:// doi.org/10.1108/01443570510585552

Parker, P. (1997). National cultures of the world: A statistical reference. Greenwood.

Patel, T., \& Rayner, S. (2015). A transactional culture analysis of corporate sustainability reporting practices. Business \& Society, 54(3), 283-321. https://doi.org/10.1177/0007650312445132

Paul, J., \& Criado, A. R. (2020). The art of writing literature review: What do we know and what do we need to know? International Business Review, 29(4), 101717. https://doi.org/10.1016/j.ibusrev.2020. 101717

Pegas, F., De, V., Weaver, D., \& Castley, G. (2015). Domestic tourism and sustainability in an emerging economy: Brazil's littoral pleasure periphery. Journal of Sustainable Tourism, 23(5), 748-769. https://doi.org/10.1080/09669582.2014.998677

Piwowar-Sulej, K. (2021). Core functions of sustainable human resource management: A hybrid literature review with the use of H-Classics methodology. Sustainable Development, 29(4), 671-693. https://doi.org/10.1002/sd.2166 
Piwowar-Sulej, K., Krzywonos, M., \& Kwil, I. (2021). Environmental entrepreneurship: Bibliometric and content analysis of the subject literature based on H-Core. Journal of Cleaner Production, 295, 126277. https://doi.org/10.1016/j.jclepro.2021.126277

Renwick, D. W. S., Jabbour, C. J. C., Muller-Camen, M., Redman, T., \& Wilkinson, A. (2016). Contemporary developments in Green (environmental) HRM scholarship. The International Journal of Human Resource Management, 27(2), 114-128. https://doi.org/10.1080/09585192.2015.1105844

Rey-Martí, A., Ribeiro-Soriano, D., \& Palacios-Marqués, D. (2016). A bibliometric analysis of social entrepreneurship. Journal of Business Research, 69(5), 1651-1655. https://doi.org/10.1016/j.jbusr es.2015.10.033

Rokeach, M. (1973). The nature of human values. Free Press.

Roskruge, N. (2011). Traditional Māori horticultural and ethnopedological praxis in the New Zealand landscape. Management of Environmental Quality: An International Journal, 22(2), 200-212. https://doi.org/10.1108/14777831111113383

Salahodjaev, R., Yuldashev, O., \& Omanbayev, B. (2016). What drives foreign direct investment into post-communist economies? MPRA Papers, 73277, 1-14.

Scharlemann, J. P. W., Brock, R. C., Balfour, N., Brown, C., Burgess, N. D., Guth, M. K., Ingram, D. J., Lane, R., Martin, J. G. C., Wicander, S., \& Kapos, V. (2020). toward understanding interactions between sustainable development goals: The role of environment-human linkages. Sustainability Science, 15(6), 1573-1584. https://doi.org/10.1007/s11625-020-00799-6

Shi, L., Han, L., Yang, F., \& Gao, L. (2019). The evolution of sustainable development theory: Types, goals, and research prospects. Sustainability, 11(24), 7158. https://doi.org/10.3390/su11247158

Shoham, A., Almor, T., Lee, S. M., \& Ahammad, M. F. (2017). Encouraging environmental sustainability through gender: A micro-foundational approach using linguistic gender marking. Journal of Organizational Behavior, 38(9), 1356-1379. https://doi.org/10.1002/job.2188

Sims Bainbridge, W. (2010). Virtual sustainability. Sustainability, 2(10), 3195-3210. https://doi.org/10. 3390/su2103195

Smith, P. B., \& Bond, M. H. (2019). Cultures and persons: Characterizing national and other types of cultural difference can also aid our understanding and prediction of individual variability. Frontiers in Psychology. https://doi.org/10.3389/fpsyg.2019.02689

Snitker, T. V. (2010). The impact of culture on user research. Handbook of global user research (pp. 257-277). Elsevier.

Sörensson, A., Bogren, M., \& Cawthorn, A. (2019). Sustainability information in large-sized companies in Europe: Does national culture matter? The International Journal of Sustainability in Economic, Social, and Cultural Context, 15(1), 45-62. https://doi.org/10.18848/2325-1115/CGP/v15i01/ 45-62

Sulich, A., \& Sołoducho-Pelc, L. (2021). Renewable energy producers' strategies in the Visegrád group countries. Energies, 14(11), 3048. https://doi.org/10.3390/en14113048

Sunil, A., Momany, M. T., \& Lutta, J. G. M. (2020). Which national and organizational cultural dimensions affect the performance of Ijv's through the sustainability development. Academy of Entrepreneurship Journal, 26(2), 1-14.

Tata, J., \& Prasad, S. (2015). National cultural values, sustainability beliefs, and organizational initiatives. Cross Cultural Management, 22(2), 278-296. https://doi.org/10.1108/CCM-03-2014-0028

Thanetsunthorn, N., \& Wuthisatian, R. (2018). Cultural configuration models: Corporate social responsibility and national culture. Management Research Review, 41(10), 1137-1175. https://doi.org/ 10.1108/MRR-08-2017-0254

Thornton, L. M., Autry, C. W., Gligor, D. M., \& Brik, A. B. (2013). Does socially responsible supplier selection pay off for customer firms? A cross-cultural comparison. Journal of Supply Chain Management, 49(3), 66-89. https://doi.org/10.1111/jscm.12014

Triandis, H. C. (1994). Culture and social behaviour. McGraw Hill.

Triandis, H. C. (1996). The psychological measurement of cultural syndromes. American Psychologist, 51(4), 407-415. https://doi.org/10.1037/0003-066X.51.4.407

Triandis, H. C. (2001). Individualism-collectivism and personality. Journal of Personality, 69(6), 907924. https://doi.org/10.1111/1467-6494.696169

Trompenaars, F., \& Hampden-Turner, C. (1997). Riding the waves of culture. Understanding cultural diversity in business. Nicholas Brealey Publishing.

United Nations. (2016). 2030 Agenda for sustainable development. https://www.un.org/ga/search/view_ doc.asp?symbol=A/RES/70/1\&Lang=E.

United Nations. (2020). What is sustainable development. https://www.un.org/sustainabledevelopment/devel opment-agenda-retired/. 
Vachon, S. (2010). International operations and sustainable development: Should national culture matter? Sustainable Development, 18(6), 350-361. https://doi.org/10.1002/sd.398

van Eck, N. J., \& Waltman, L. (2014). Visualizing bibliometric networks. In Measuring scholarly impact (pp. 285-320). Springer International Publishing. https://doi.org/10.1007/978-3-319-10377-8_13.

Vitolla, F., Raimo, N., Rubino, M., \& Garzoni, A. (2019). The impact of national culture on integrated reporting quality: A stakeholder theory approach. Business Strategy and the Environment, 28(8), 1558-1571. https://doi.org/10.1002/bse.2332

Wang, Y.-C., \& Chiou, S.-C. (2018). An analysis of the sustainable development of environmental education provided by museums. Sustainability, 10(11), 4054. https://doi.org/10.3390/su10114054

Von Weizsaecker, E., \& Wijkman, A. (2018). Come On! Capitalism, short-termism, population and the destruction of the Planet. In Come On! (pp. 101-204). Springer.

Williams, R. (1988). Resources of hope. Verso.

Williamson, D. (2002). Forward from a critique of Hofstede's model of national culture. Human Relations, 55(11), 1373-1395. https://doi.org/10.1177/00187267025511006

Willmott, R. (2000). The place of culture in organization theory: Introducing the morphogenetic approach. Organization, 7(1), 95-128. https://doi.org/10.1177/135050840071006

Wilson, J. P. (2015). The triple bottom line. International Journal of Retail \& Distribution Management, 43(4/5), 432-447. https://doi.org/10.1108/IJRDM-11-2013-0210

World Commission on Environment and Development. (1987). Our common future. Oxford University Press.

Worthington, I., Britton, C., \& Thompson, E. (2018). The business environment: A global perspective. Pearson.

Yoder-Wise, P. S. (2018). The importance of culture. The Journal of Continuing Education in Nursing, 49(5), 195-196. https://doi.org/10.3928/00220124-20180417-01

Zainuddin, M., Mahi, M., Akter, S., \& Yasin, I. M. (2020). The role of national culture in the relationship between microfinance outreach and sustainability: A correlated random effects approach. Cross Cultural \& Strategic Management, 27(3), 447-472. https://doi.org/10.1108/CCSM-12-2019-0219

Zhang, Y., Huang, K., Yu, Y., \& Yang, B. (2017). Mapping of water footprint research: A bibliometric analysis during 2006-2015. Journal of Cleaner Production, 149, 70-79. https://doi.org/10.1016/j.jclepro. 2017.02.067

Zheng, X., Wang, R., Hoekstra, A. Y., Krol, M. S., Zhang, Y., Guo, K., Sanwal, M., Sun, Z., Zhu, J., Zhang, J., Lounsbury, A., Pan, X., Guan, D., Hertwich, E. G., \& Wang, C. (2021). Consideration of culture is vital if we are to achieve the sustainable development goals. One Earth, 4(2), 307-319. https://doi. org/10.1016/j.oneear.2021.01.012

Zhu, B., Habish, A., \& Thogerseb, J. (2018). The importance of cultural values and trust for innovation: A European study. International Journal of Innovation Management, 22(02), 1850017. https://doi.org/ $10.1142 / \mathrm{S} 1363919618500172$

Publisher's Note Springer Nature remains neutral with regard to jurisdictional claims in published maps and institutional affiliations. 